\title{
Mortgage Securities in Emerging Markets
}

\author{
by \\ Loïc Chiquier, Olivier Hassler, and Michael Lea*
}

Financial Sector Operations and Policy Department

The World Bank

World Bank Policy Research Working Paper 3370, August 2004

The Policy Research Working Paper Series disseminates the findings of work in progress to encourage the exchange of ideas about development issues. An objective of the series is to get the findings out quickly, even if the presentations are less than fully polished. The papers carry the names of the authors and should be cited accordingly. The findings, interpretations, and conclusions expressed in this paper are entirely those of the authors. They do not necessarily represent the view of the World Bank, its Executive Directors, or the countries they represent. Policy Research Working Papers are available online at http:/lecon.worldbank.org.

\footnotetext{
* Loïc Chiquier is the Leader of the Housing Finance Business Group (lchiquier@worldbank.org) and Olivier Hassler (ohassler@,worldbank.org) is Senior Housing Finance Specialist, both in the Financial Sector Operations and Policy Department of the World Bank. Michael Lea is Executive Vice President of Global Markets at Countrywide Financial Corporation (michael_lea@countrywide.com).
} 


\section{Mortgage Securities in Emerging Markets}

\section{Overview}

\section{A. Purpose and Objectives of the Study}

Despite its recognized economic and social importance, housing finance often remains under-developed in emerging economies. Residential lending is typically small, poorly accessible and depository-based. Lenders remain vulnerable to significant credit, liquidity and interest rate risks. As a result, housing finance is relatively expensive and often rationed. The importance of developing robust systems of housing finance is paramount as emerging economy governments struggle to cope with population growth, rapid urbanization, and rising expectations from a growing middle class.

The capital markets in many economies provide an attractive and potentially large source of long-term funding for housing. Pension and insurance reform has created large and rapidly growing pools of funds. The advent of institutional investors has given rise to skills necessary to manage the complex risks associated with housing finance. The creation of mortgage-related securities (bonds, pass-throughs and more complex structured finance instruments) has provided the multiple instruments by which housing finance providers can access these important sources of funds and better manage and allocate part of their risks.

The use of mortgage-related securities to fund housing has a long and rich history in industrial countries. Mortgage bonds were first introduced in Europe in the late $18^{\text {th }}$ century and are a major component of housing finance today [EMF 2002]. Mortgage pass-through securities were introduced in the United States in the early 1970s and along with more complex structured finance instruments now fund more than $50 \%$ of outstanding debt in that country [Lea 1999]. Today, mortgage-related securities have been issued in almost all European and developed Pacific Rim countries.

There have been numerous attempts to develop mortgage securities to secure longer term funding for housing in emerging economies. The view has been that such instruments can help lenders more efficiently mobilize domestic savings for housing, much as they do in industrial countries. In addition, mortgage securities are pursued to develop and diversify fixed-income markets as a supplement to government bonds for institutional investors.

Despite the strong appeal of financing housing through the capital markets, there are significant barriers to the development of mortgage securities in emerging markets. Their success is dependent on many factors, starting with a strong legal and regulatory framework and liberalized financial sector, and including a developed primary mortgage 
market. Perhaps not surprisingly, the experience in developing mortgage securities in emerging markets has been mixed. This paper reviews the experience of introducing mortgage securities in emerging markets and explores the various policy issues related to this theme.

The organization of the paper is as follows. First, we review the rationales for introducing mortgage securities to fund housing. Second, we list the many pre-requisites that underlie successful introduction. Third, we explore the role that government can play in developing these instruments, from both a theoretical and functional perspective. Fourth, we examine the experience of issuing mortgage securities in emerging markets through short case studies of their use. From this examination we then summarize the lessons learned from these experiences, both in general and with specific reference to the proper role of the government. Finally, we offer observations on the way forward to increase the use of mortgage securities in emerging markets.

The note also discusses the various forms of state related support (guarantees, liquidity support, mandatory investment, tax breaks, and issuing privileges) that have been offered in order to secure the credibility and affordability of nascent mortgage securities, but that may also raise significant concerns about contingent liabilities and market distortions. The regulatory dimension of mortgage securities and securitization companies is an important determinant of their success and is addressed as well.

\section{B. Summary of Findings}

Despite numerous attempts, there have been limited successes in introducing mortgage securities in emerging markets on a significant scale. There are two major reasons for this result. First, the infrastructure requirements for mortgage security issuance are demanding, time consuming and costly. As discussed below, there are complex legal and regulatory pre-requisites for mortgage security issuance. It takes time and significant government support to develop the proper legal and regulatory infrastructure. This infrastructure also adds to the cost of funding through securities issuance, often making it uneconomic.

There are also challenging primary market requirements. Although not inconceivable, it is highly unlikely that mortgage securities can be successfully issued in countries with weak and under-developed primary mortgage markets. There must be a modicum of standardization in mortgage instruments, documents and underwriting, reasonable standards of servicing on the part of lenders and issuers and professional standards of property appraisal. Capital market funding can provide a strong incentive to improve primary market standards in these areas, but there can be no substitute for a certain degree of market development preceding introduction of new funding vehicles.

Even in countries with reasonably well-developed primary markets there has been spotty success introducing mortgage securities. A major reason has been a lack of issuer need for capital market funding. Lenders seeking to access the capital markets through 
mortgage securities do so in order to better manage capital and risk and to lower cost and diversify funding sources. In most circumstances, the cost of wholesale funding through mortgage securities is higher than retail funding, at least in terms of the relative cost of the debt. If lenders are not capital or liquidity constrained, they may view mortgage securities as excessively costly and complex. Alternatively, some lenders confronted with serious financial constraints and therefore strongly motivated have managed to overcome the obstacles against the development of securitization.

In some cases, the mortgage security design has perhaps been overly complex for the environment. Mortgage securities can be complex or simple products or structures (mortgage bonds, agency bonds, securitization, structured finance etc.), differently stripping and pricing the related credit and/or market risks. The use of particular instruments needs to be in line with the standards and prerequisites of investors and the underlying legal infrastructure, as well as the funding and residual risk exposure needs of primary lenders. Institutional models should be adjusted to the development stage of financial and mortgage markets. Multiple legal and regulatory challenges must to be addressed, in particular in civil code countries.

Governments have been active in trying to stimulate issuance of mortgage securities in emerging markets. One lesson learned is that government involvement is not a guarantee of success. There must be an underlying market need for capital market funding and investor demand for mortgage securities. Government's most important role is as a facilitator, removing obstacles to issuance and investment, and strengthening the legal and regulatory environment surrounding housing finance. In a number of countries, institutions with characteristics similar to the government-sponsored enterprises in the US have been created. Although the jury is still out as to their potential role and importance, in most cases they have had at best a modest impact. Policy makers must be aware of the potential risks and distortions to the system that such institutions present. A level playing field and sunset clauses for such government support are important considerations.

Does the limited success to date mean that mortgage securities are not relevant for emerging markets? By no means do we ascribe to this conclusion. Mortgage securities are the vehicle to tap capital markets for funds for housing and can improve the accessibility and affordability of housing and allow lenders to better manage the complex risks of housing finance. In markets with demonstrable need with appropriate instruments and institutions, mortgage securities can make a real contribution to housing finance. We believe that the use of such instruments will grow over time as housing demand increases, as lenders become more capital and liquidity constrained and as investors become more familiar with their risks.

It is important to note that in many emerging economies, interest rate risk associated with housing finance is mostly if not entirely borne by the borrower. In volatile economies it is likely that this restrains housing demand and poses a systemic risk to the system. Institutional investors are often better able to manage such risk, reflecting their ability to invest in proper models and expertise and access markets to diversify and manage the 
risk. Thus we believe mortgage security issuance in emerging economies will to some degree parallel the introduction of more fixed rate lending options.

\section{Types of Mortgage Securities}

What do we mean by mortgage security? There are a number of different types of instruments that can be used to tap the capital markets. In this paper we focus on 5 generic types.

a. Whole Loan Sales: Although not a security, the sale of whole loans can be an important way for primary lenders to raise funds and manage risk. Whole loan sales involve the sale of mortgages, either individually or more commonly in pools, to other lenders or investors. Examples of whole loan sales include the sale of pools in their entirety, participation or recourse basis, by savings and loan institutions in the US in the 1960s and 1970s. ${ }^{1}$ Whole loans may be sold through brokers, relationships (e.g., the seller delivers loans on a regular basis to the buyer)) or wholesalers who aggregate loans from a variety of sources and sell them to investors.

b. Agency Bonds: These are bonds issued by agencies specialized in mortgage finance at a secondary (i.e., not the loan origination) level. Issuers include liquidity facilities that refinance primary market lenders (discussed below) and [the retained portfolio activities of] the mortgage GSEs in the US. ${ }^{2}$ Their bonds are not specifically backed by mortgage loans but the assets of the issuers are almost entirely mortgages or loans backed by mortgages. The bonds are obligations of the issuers and can be straight or callable.

c. Mortgage Bonds: These are bonds that are issuer obligations and issued against a mortgage collateral pool. Investors have a priority claim against the collateral in the event of issuer bankruptcy. The issuer may be a specialized mortgage bank, as is the case in Denmark, Germany and Sweden, a commercial bank as is the case of Chile, Czech Republic or Spain, or a centralized issuer as is the case of France or Switzerland. The collateral pool may consist of all of the qualified assets of the issuer, as is the case with the German Pfandbriefe, a specified pool as in the case of US savings and loans and the recent issue by Halifax Bank of Scotland in the UK, or individual loans as in Chile and Denmark (the individual bonds are aggregated into large series). The bonds may be straight (non-amortizing) or pass-through (in which

\footnotetext{
${ }^{1}$ In participation agreements, the seller retains a portion of the pool and thus shares the risk with the purchaser on a pari-pasu basis. In recourse transactions, the seller retains some or all of the risk of default by agreeing to repurchase loans in default. The recourse may be limited to a certain amount or percentage of the pool balance.

${ }^{2}$ GSE stands for Government Sponsored Enterprise, a special class of institutions in the US. The GSEs are government chartered, limited purpose corporations that are owned by either their members or the general public. They enjoy a number of tax and regulatory privileges that translate into lower funding costs. The best known enterprises, Fannie Mae and Freddie Mac and the Federal Home Loan Banks are described in Lea, 1999.
} 
mortgage principal is "passed through" to investors as received from borrowers).

d. Mortgage Pass-through Securities: Pass-throughs (PTs) are securities issued against a specific collateral pool subject to cash flow matching. The balance on the PT is always equal to the balance on the mortgages in the pool and the cash flows received from borrowers are passed through to investors, with a delay and deduction for servicing and guarantee fees. Pass-throughs are typically not the liability of the issuer and feature credit enhancement through a variety of techniques described below. They may be issued by lenders or conduit institutions. ${ }^{3}$ The best known PTs are the securities guaranteed by Ginnie Mae and those issued by Fannie Mae and Freddie Mac in the US. ${ }^{4}$

e. Mortgage Pay-through Securities: Pay-throughs are multiple securities issued against a single collateral pool. They may be closed end, wherein there is a fixed collateral pool and all securities are issued at the outset of the transaction, or open end in which the collateral pool and securities can be increased over time (subject to constraints). These securities modify cash flows between borrowers and investors to meet the needs or requirements of investors. Examples of pay through securities include mortgage strips in which separate securities that are backed from either the principal and interest from a mortgage pool are sold, and collateralized mortgage obligations (CMOs) in which a number of securities that repay principal sequentially are issued. Most mortgage security issuance by banks in developed and emerging markets are pay-through structures.

\section{Why Are Mortgage Securities Important?}

Mortgage securities can perform a number of valuable functions in emerging economies. Their introduction and use can improve housing affordability, increase the flow of funds to the housing sector and better allocate the risks inherent in housing finance.

In economies with pools of contractual savings funds, mortgage securities can tap new funds for housing. Institutional investors (pension, insurance funds) with long term liabilities are potentially important sources of funds for housing as they can manage the liquidity risk of housing loans more effectively than short-funded depository institutions. Although in some countries, these investors are also involved in loan origination and servicing, it is not their core mission or competency. Efficiencies can be gained through passive investment in mortgage securities by institutional investors, allowing depositories and specialist mortgage companies perform the other functions. An increase in the supply

\footnotetext{
${ }^{3}$ Conduits are centralized institutions that purchase loans from lenders and issue mortgage securities. Fannie Mae and Freddie Mac have conduit functions and there are over 20 major private conduits in the US as well.

${ }^{4}$ For more detail on mortgage security characteristics, see Fabozzi 1997, 2001.
} 
of funds can, all other things equal, reduce the relative cost of mortgage finance and improve accessibility to finance by the population.

Funding through the capital markets through issuance of mortgage securities can increase the liquidity of mortgages, thereby reducing the risk for originators and the risk premium charged by lenders. The ability to dispose of an asset within a reasonable time and value, a crucial factor to mobilize long term resources, is a service that capital markets, as opposed to banking systems, can provide. A frequently expressed reluctance of primary market financial institutions to offer housing loans is a lack of long-term funds. ${ }^{5}$ Access to the long term funds mobilized by institutional investors can reduce the liquidity risk of making long term housing loans, increasing their affordability and improving the access to funds for home buyers.

A third rationale for introducing mortgage securities is to increase competition in primary markets. The development of capital market funding sources frees lenders from having to develop expensive retail funding sources (e.g., branch networks) to mobilize funds. Securitization for example can allow small, thinly capitalized lenders who specialize in mortgage origination and servicing to enter the market. These lenders can increase competition in the market and can lower margins and introduce product and technology innovation into the market. The experience of Australia in the 1990s provides dramatic evidence of the power of capital-market funded lenders to change a market. The market entry of wholesale funded specialist lenders led to a reduction of 200 basis points in mortgage spreads during the 1994-1996 time period [Gill 1997].

Increasing competition and specialization can in turn increase efficiency in the housing finance system. Greater specialization can lead to cost-savings and reduce spreads. The phenomenon of unbundling (Figure 1) has been associated with development of secondary mortgage markets. As the functional components of the mortgage process are unbundled, specialists emerge and obtain market share through scale economies in processing, access to information and technology and risk management.

\footnotetext{
5 There is a degree of speciousness to this argument, however. In most countries, depository institutions have a core of long term deposits. Although the contracts may be short term, they are typically rolled over and can fund long term housing loans. An institution can provide a significant percentage of its loans for housing while accepting only a modest amount of liquidity risk. This statement frequently masks other reasons for not providing housing loans including high transactions costs, high perceived credit risk etc.).
} 


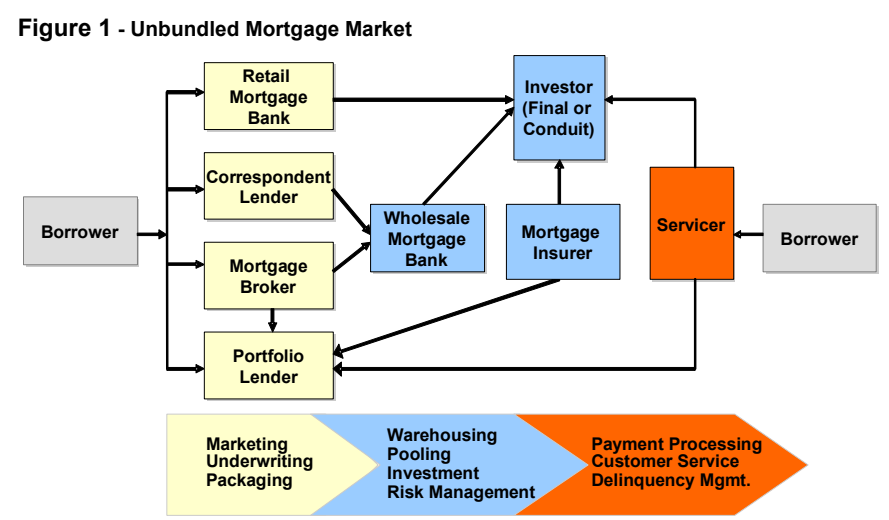

An additional virtue of capital market funding is that it can engender the lengthening of the maturity of loans. Lenders with short-term liabilities often offer shorter term mortgages. Origination of long-term housing loans can improve affordability particularly in low interest rate environments.

Capital market funding can also help smooth housing cycles. Lenders relying on deposits may be subject to periodic outflows due to economic downturns or widening differentials between deposit and alternative investment rates (e.g., if deposit rates are regulated). Access to alternative sources of funds through the capital markets may allow lenders to keep providing housing finance throughout the cycle.

\section{What Are the Pre-requisites for Issuing Mortgage Securities?}

First and foremost, there must be a demonstrable market need for the type of funding offered by the capital markets. It is almost always the case that capital market (wholesale) funding is more expensive than retail (typically deposit) funding on a debtonly, non-risk adjusted basis. ${ }^{6}$ Why would a lender look to the capital markets for funding? There are several reasons:

1. The lender may be capital constrained (at least on the margin). In such circumstances, the all-in costs of wholesale funding (through asset sale) may be less than retail funding taking into account the high expense of equity capital. In this case, the capital savings afforded by securitization (if the lender can get the assets off balance sheet for risk-based capital purposes) can more than make up for the higher cost of debt. From a balance sheet and regulatory capital management perspective, however, the lower risk weight of residential mortgages may lead the lender to securitize other classes of assets (e.g., consumer loans with

\footnotetext{
${ }^{6}$ That is before consideration of the operating costs of raising funds through branch deposits. These costs are often ignored or understated, as lenders may view them as fixed or allocate them to other activities of the branch. The transaction costs of wholesale funding need also to be taken into account.
} 
a $100 \%$ risk weight rather than mortgage loans with a $50 \%$ risk weight (or lower under Basel II).

2. The lender may be liquidity constrained. Taking into account a liquidity risk premium, wholesale funding may be cheaper than retail, particularly on the margin where the alternative to wholesale funding is raising additional funds through retail sources which may entail pricing up the stock of outstanding deposits (buying out the base). Lenders may want to diversify their funding sources as well. Even if wholesale funding is currently more expensive than retail, a lender may wish to create a wholesale funding channel to better manage liquidity and funding risk in the future. The more liquid the lender, however, the less likely they are going to ascribe a value to the liquidity premium of mortgages.

3. The lender may have cash flow risk management needs. For example, it may wish to offer products the characteristics of which are difficult to manage via traditional retail means, such as a medium or long term fixed rate mortgage. Onbalance sheet funding of such loans entails significant cash flow risk, both interest rate risk if not match funded and prepayment risk if the borrower has that option. Lenders offering reviewable rate ARMs (a common emerging market mortgage instrument) will have less need to fund these through wholesale sources as they entail virtually no interest rate or prepayment risk. The countries with the greater proportion of funding coming from the wholesale markets (Denmark, Germany, US) have high proportions of mortgage loans with extended fixed interest periods [EMF, MOW 2003]. Lenders may also wish to issue securities to manage liquidity risk. This risk is best judged from a portfolio perspective and may not be significant until mortgage assets constitute a significant portion of total assets.

Second, there must be a demonstrable investor demand for mortgage-related securities. Specifically there must be a class of investors with an appetite and capacity for securities backed by mortgages. In certain circumstances, the demand may come from other lenders. If there is a geographic mismatch, for example, some lenders may be asset rich and others liability rich (historically the case in the large US market). The development of a secondary mortgage market can facilitate the movement of funds between regions. More likely, the demand will come from institutional investors such as insurance companies or pension funds. These investors will have long term liabilities and thus seek longer term assets to match their cash flow and investment needs. The task is to get these investors to fund housing through purchase of mortgage securities (solving the institutional mismatch).

When will investors be interested in mortgage-related securities? There are several prerequisites:

1. Mortgage securities must offer attractive risk-adjusted returns. In most cases, institutional investors will look to mortgage securities as an alternative to government bonds that provide a benchmark yield as they typically represent a default-risk free, liquid investment alternative. Investors will seek a premium over 
government bond yields to reflect credit risk, liquidity risk and transactions costs of purchasing and managing the assets. The premium required by investors may be reduced if credit enhancement (either by third parties or through structuring) is credible and if there is some market liquidity (e.g., if there are market makers, a function often served by broker dealers, committed to trade at posted prices with acceptable bid-offer spreads). Likewise mortgage securities can be an alternative to corporate bonds, offering greater security reflecting their collateral backing.

2. Investors must have a capacity for mortgage-related securities. In markets in which governments are excessively issuing debt, the capacity of institutional investors to purchase mortgage securities may be limited or non-existent (i.e., the government may crowd out other issuers). Capacity may also be related to the liability mix of the investors. If investors have short duration liabilities, they will seek short duration assets as a match. Investors may prefer short duration assets in volatile environments to minimize the price risk in their portfolios.

3. Investors must be able to invest in mortgage-related securities. This is an infrastructure development issue. Investors must have the legislative and regulatory authority to invest in such assets, and the regulatory treatment (e.g., for capital adequacy, liquidity and asset allocation purposes, eligibility to technical reserves) must be well defined. Their regulatory framework -like a minimum performance benchmark- may also force them to prefer secure, shorter-term and liquid securities.

Even if there are willing issuers and investors, there are a number of infrastructure requirements underlying the development of mortgage capital markets. Most important are the legal pre-requisites. Without going into detail regarding each of the requirements we can state that issuance will depend on:

1. An adequate legal, tax and accounting framework for securitization and secured bond issuance. The accounting and tax treatment of mortgage securities for both issuers and investors must be clear and complete. Adequate disclosure of information on the collateral and the issuer is necessary to assess risk.

2. Facilities for lien registration: Mortgage securities are backed by mortgage loans. There must be an accurate and timely recording of the lender's interest in the collateral. Recording of liens must involve modest cost as well.

3. Ability to enforce liens: Because investors can be last resort bearers of the credit risk attached to underlying mortgages, the enforceability of the lender's security interest is a major determinant of the attractiveness of mortgage-related securities. If liens are not enforceable, there is little to distinguish mortgage loans from unsecured debt (only, perhaps, a belief that the likelihood of default on an owner-occupied dwelling is less than that of a consumer debt). Lack of enforceability causes mortgage lending to not be perceived as safe a field of activity in many developing countries as in mature markets.

4. Ability to transfer (assign) security interest: In the case of securitization, there is a transfer of the lender's beneficial interest to the investor. The legal system must recognize and record the transfer and it should involve only a modest cost. In the 
case of mortgage bonds, the ability to transfer beneficial interest is important in the event of bankruptcy of the issuer.

5. Protection of investors against bankruptcy of originator or servicer. The credibility of the legal provisions ensuring bondholders that the collateral backing their assets would stay out of the reach of other creditors in case of insolvency proceedings is of the essence. For securitization purposes, the concept of a special purpose vehicle or other construct that isolates the collateral pool from the issuer/servicer is essential to obtain off-balance sheet accounting and capital treatment for the issuer. The concept of a bankruptcy remote vehicle is critical for the development of securitisation and is often lacking in developing country law.

There are a number of primary market pre-requisites as well. These include:

1. Standardization of documents and underwriting practices: The more standardized are the products, documents and underwriting practices, the lower the transactions cost of due diligence and credit enhancement costs in the case of securitization. This constraint is less stringent for mortgage bonds, which shift the emphasis of standardization from the loans to the securities, but it is essential that mortgage bond legal frameworks define clear quality lending requirements. Standardization contributes to liquidity and thus lower yield premiums on mortgage securities.

2. High quality servicing and collection: Investors in mortgage securities depend on external agents to collect and remit payments and deal with arrears. A secondary mortgage market is more likely to develop and the relative cost of funds is likely to be lower if investors have confidence of in the ability of issuers to perform this function, the greater likelihood of market development and the lower the relative cost of funds.

3. Professional standards of property appraisal: Investors must be confident in the value of the collateral underlying the lien.

\section{What Role Can Government Play in Developing Mortgage Securities in Emerging Markets?}

\section{A. Theoretical Considerations}

All formal sector financial intermediation exists with the support of some government intervention. At one extreme, the government may intervene only through the maintenance of a legal system capable of enforcing private contracts. At the other extreme, the government may own and operate the housing finance system or even the entire financial system. Most countries operate in between these two extremes, usually with a blend of policies that reflects the traditions and circumstances of that country.

The clear trend in financial sector policy is to treat housing finance as part of the broader financial markets, and not as special circuits of credit allocation. In this context, the major polices affecting housing finance are those that affect the operation of banking 
systems and financial markets. Housing finance should be seen within the broader purview of financial sector liberalization. If the banking system and financial markets have not been substantially liberalized, attempts to create a capital market funding system may be ineffective or counterproductive (e.g., increasing the distortions associated with directed credit, and/or improperly concentrating the risks related to housing finance into the hands of the state).

Within this domain, however, it is recognized that housing lending has special characteristics. It is a major form of secured or collateralized lending. The relative efficiency of housing finance from a primary market basis depends critically on the legal infrastructure supporting the security of collateral and lender access to it. It is no accident that those countries enjoying the highest level of development of their housing finance systems, as defined in terms of the relative availability of mortgage credit and its relative cost are those countries with the legal systems in which property rights are strongly enforced. Thus, a necessary government involvement to generate capital market funding of housing is creation and maintenance of a strong legal system supporting collateralized lending.

Government clearly has an enabling role to play in creating mortgage capital markets. Government can and should act to remove onerous laws, taxes and regulations that preclude or disadvantage mortgage securities, and reflect in regulatory regimes the safety that mortgage securities can provide reflecting their collateralization. For example, stamp duties on securities registration can inhibit issuance (e.g., in India where in some states they are as high as 12 percent). The requirement that borrowers consent to a transfer of ownership adds to the cost and disadvantages mortgage securitization. The trade tax in Germany has been a significant disadvantage for securitization. It is particularly important for legislators and regulators to create sound and thorough guidelines for the creation and bankruptcy remoteness of special purpose vehicles (SPVs) and mortgage bonds. Securitization requires that the SPV have full rights over transferred assets and the proceeds from their liquidation, as well as the decision to liquidate them. Mortgage bond investors must have indisputable priority rights to the collateral which should not be part of the general bankruptcy estate in the event of issuer's bankruptcy, and ideally a priority right over the other assets comprising of the estate in case the of a deficiency in the cover pool.

Government may seek to stimulate mortgage capital market development to improve the allocation of risk in the financial system. Two risks that are somewhat unique to housing finance because of its long term nature are liquidity risk and cash flow risk.

Liquidity risk refers to the risk that money will be needed before it is due. Liquidity risk can arise due to the long term nature of mortgage loans. Individual mortgages may not be readily marketable (converted into cash). A lender faced with short-term and unstable sources of funds (e.g., deposits, short term bank loans) may not make mortgages due to the risk that it cannot meet cash outflow needs by selling its loans. Illiquid assets that cannot be pledged as collateral for short term borrowing also increase liquidity risk. 
Liquidity risk is not unique to housing finance but rather a broader financial sector stability issue. In modern financial markets, central banks provide the ultimate back-stop against liquidity risk. In addition, deposit insurance reduces the likelihood of massive withdrawals from depository institutions. However, the long term nature of mortgage securities suggests that the risk is greater than for other types of finance and is frequently cited as a reason why banks won't provide housing finance in emerging markets. A relatively easy way for government to improve the liquidity of mortgage assets is to accept mortgage securities as collateral at the discount window (open market transactions with adjusted haircuts). But governments may also wish to support more directly and rapidly the development of mortgage capital markets as a way to tap long-term funds and help lenders manage the maturity mismatch.

Cash flow risk is an issue for lending institutions with liabilities with characteristics that do not match the characteristics of their assets. As the savings and loans in the U.S. learned, there is substantial interest rate risk associated with making long term fixed rate mortgages funded by short-term (essentially variable rate) deposits. While variable rate mortgages reduce the interest rate risk for lenders, they increase it for borrowers, which may lead to high rates of default in volatile economies. Lenders may avoid investing in certain types of mortgages (e.g., long term, fixed rate prepayable loans) due to their inability to manage the interest rate or prepayment risk of the asset - in particular if there are no hedging instruments available. Capital market funding can facilitate a reallocation of cash flow risk if investors can be found with funding characteristics similar to those of the mortgage contracts and/or the capabilities to manage the risks of complex instruments like mortgages. ${ }^{7}$

Developing mortgage capital markets can foster financial market and economic stability. Lenders subject to significant liquidity risk may ration the availability and terms of mortgages, which in turn may lead to cycles in housing construction and economic activity. Lenders subject to interest rate risk may pose a danger to safety and soundness of the financial system. For both reasons, the government may wish to stimulate capital market funding if it achieves a more desirable allocation of risk.

A true secondary market for mortgage loans based on securitization may improve the allocation of mortgage credit risk by diversifying it across geographic areas.

Traditionally, American mortgage lenders operated on a narrowly defined geographic basis, lending only to those clients and in those markets in which they could efficiently gather information on borrowers and properties. This geographic focus, which was enshrined in the charters of savings and loans in the U.S. until the early 1980s, exposes lenders to concentration risk that can be diversified through lending in a wider geographic area. ${ }^{8}$ Geographic diversification can be obtained through operating across

\footnotetext{
${ }^{7}$ Management of this risk (or the inability to do so) is frequently referred to as an institutional mismatch, that is a mismatch between the holders of long-term funds (institutional investors) and the users of long term funds (mortgage lenders).

${ }^{8}$ Geographically restricted institutions may also be subject to periodic funds shortages if the local demand for credit exceeds the local supply of savings. Conversely, they may find themselves with an excess supply of funds if local loan demand is weak. Correcting a geographic mismatch between capital surplus and
} 
markets that are not correlated or are inversely correlated with each other. Alternatively, it can be obtained through the sale and purchase of loans between institutions located in different market areas.

If mortgage capital markets are desirable, will they not develop on their own? If sufficient legal and regulatory frameworks as well as institutional investors exist, lenders can issue bonds or mortgage-backed securities or sell pools of whole loans to obtain long term funds and re-allocate the risks inherent in mortgage lending. But the fact that such funding is available does not necessarily mean it will be used. Lenders may not issue mortgage securities or sell loans due to the higher cost associated with wholesale finance. The higher cost may reflect the transactions cost of issuing bonds or securities or selling whole loans, and/or the perceived credit-worthiness of the issuer and the collateral. ${ }^{9}$

The issuance of mortgage securities involves significant transactions costs in the form of legal, regulatory, investment banking, rating agency and other fees. These costs are typically fixed fees, invariant to the size of the issue. If the volume of loans to be financed is small, the transactions costs may render the financing uneconomic. In addition, small size securities are less liquid and investors charge a liquidity premium to invest in them. Lenders may reduce these costs by creating a jointly owned facility (liquidity facility or conduit) to pool assets and issue larger securities, spreading the transactions cost over a larger base and creating more liquid securities.

Investor credit risk concerns are a major potential obstacle to the creation of mortgage capital markets in emerging markets. Investors may not be comfortable with the credit quality (e.g., if foreclosure is weak or non-existent or if the performance of mortgage markets has been affected by a crisis) or the issuer (e.g., a newly created entity, whether a primary lender or secondary facility, a small lending institution or one with a weak capital base as in the case of banks coming out of a financial sector crisis). It also takes time before investors can value the novelty and complexity of such securities. The state may then provide a guarantee - or preferably sell it for a limited period of time - to enhance qualified mortgage securities in order to create trust of investors, or reduce the resulting cost of funds notably for social housing finance (e.g., Colombia since 2002). This position may be justified if reforms are under way to improve the lending and capital market infrastructure and issuer credibility.

Generally speaking, mortgage capital markets are not the proper solution for weak legal protection of property rights and mortgage lending. Investors will rightly be skeptical of securities backed by mortgages and demand hefty premiums or shun them altogether. Shifting the risk to the government without addressing the fundamental legal issues creates a moral hazard, which can lead to excessively risky lending.

deficit regions is another rationale for the encouragement of capital market funding of housing. This rationale is less important if lenders operate on a nationwide basis.

${ }^{9}$ In some markets, lenders may not be able to pass along higher funding costs to borrowers due to the political sensitivity of housing loans. Alternatively there may be a dominant depository lender that sets prices in the market based on retail rather than wholesale funding benchmarks. 
Even if mortgages are viewed as good quality assets, the underwriting of credit risk can be expensive. Individual mortgages are small value assets that are relatively expensive to underwrite because investors must obtain information on both the borrower and the property. In addition, investors are subject to information asymmetries, which can increase the cost of underwriting credit risk, and in the limit preclude institutional investment.

Mortgage credit risk is best managed at the local level. Lenders operating on a local basis can gather information and monitor borrowers and properties more cost effectively than lenders operating at a distance. Capital market investors are at an inherent disadvantage in managing mortgage credit risk due to their lack of retail outlets and access to local information. Thus they must depend on agents (the lenders) to properly underwrite and service mortgage investments. In so doing, they are exposed to agency risk, which is the risk that a divergence of interest will cause an intermediary to behave in a manner other than that expected. The monitoring of these agents creates costs for the investor, which may preclude their investment.

The high costs of underwriting and monitoring credit and agency risk are major deterrents to capital market funding of housing. Thus, in order to invest in housing, capital market investors demand structures (e.g., mortgage bonds or securities) that substantially reduce or eliminate these risks. In developed financial systems, institutions such as mortgage and bond insurers and senior-subordinated securities structures have evolved as private market solutions to the managing these risks (credit enhancement). ${ }^{10}$ Rating agencies can assess and monitor the performance of lenders and third party credit enhancers and thus improve the information flow as well.

In many emerging economies, by contrast to more developed economies, the perception and reality of mortgage credit risk are high - notably because of catastrophic elements related to past or future severe macro economic shocks, de-capitalized banks, ineffective legal protections (foreclosure, title), regulatory capriciousness and market distortions. The potential for such events is reflected through the level of credit enhancement expected by MBS investors (frequently more than 10\%). This credibility issue reduces the attractiveness of any securitization solution, as issuers view such structuring solutions as excessively costly (and offering them no capital relief), and there may not be any private third-party enhancement solution (for the same reasons of missing pre-requisites or small and nascent markets). In addition, many emerging countries cannot rely on the presence of several external rating agencies disposing of sufficient expertise and proper methodologies to rate mortgage securities (often creating a chicken and egg problem about the scale security issuance and the presence of rating agencies). In such cases, government involvement to reduce perceived credit risk (e.g., through public default

\footnotetext{
${ }^{10}$ In a senior-subordinated structure, two primary classes of securities are created - a senior class and a subordinated class. The subordinated class functions as the credit enhancement for the senior class because, should any defaults on the underlying mortgages occur, payments that would otherwise be made to the subordinated class are diverted to the senior class to the extent required to make the scheduled interest and principal payments. Accordingly, the majority of the credit risk is concentrated in the subordinated class.
} 
insurance fund or public securitization conduit) can accelerate access to capital markets funding for housing lenders. When considering such involvement, a government should ask the following questions:

1. Does the demand for government involvement reflect the non-existence of or limited capacity for private market solutions (e.g., mortgage insurance, payment guarantees provided by private financial institutions) or simply a desire on the part of lenders for cheaper financing but unlikely to increase the flow of funds to housing?

2. Can a public institution or guarantee program effectively manage and price the risks it takes? Will it have the incentives, autonomy and capital to operate effectively without creating a large contingent liability for government?

3. Once created, is there a mechanism for eventual privatization or sunset so that the government does not crowd out the private sector?

4. Is there a clear and narrowly defined mission with clear accountability for the managers of the institution?

Although both economic and political rationales for government involvement to stimulate mortgage capital market development exist, it is important to note that such involvement comes at a cost. Shifting risk to the government creates additional costs to monitor agents and reduce the potential for excessively risky lending and adverse selection. Government guarantees may be mis-priced for political reasons and government-supported institutions can exploit their monopoly status. Thus the costs and benefits of all interventions need to be carefully weighed.

There is no distributional rationale for government involvement in capital market funding. To attract institutional investors, mortgages must be market priced. If the funds for subsidizing mortgage borrowers come from savers or private investors, they will not supply sufficient capital to meet demand. As a result, the institutions will have to resort to non-price rationing of mortgage credit during periods of rising demand. Their lending activities will crowd out other intermediaries from the market and potentially distort capital allocation. Affordability issues can be better addressed through mortgage design and direct borrower income or down-payment support.

In sum, the rationale for government involvement in developing the capital market funding of mortgages depends on the ability and relative cost of managing the various risks of mortgage investment, which in turn depends on the existence of institutions and markets to manage these risks. In general, the more developed is the financial system the more likely it is that the private sector can efficiently manage risk and allocate long term resources to housing. The fact that private markets are constantly evolving also suggests that the institutions and incentives created by government for one set of market conditions may not continue to be needed in a different set of conditions. Thus the issue of the life cycle of government involvement needs to be addressed. 


\section{B. Functions}

If a government seeks to simulate development of mortgage capital markets, there are a number of ways to proceed. These include creating new public institutions, providing guarantees for the securities issued by private sector institutions, and providing investor and/or issuer incentives for mortgage securities [Lea 1999]. In general, government involvement should be targeted, transparent, budgeted and temporary.

Institutions: Government may play an important role in catalyzing the capital market funding of housing through the creation and support of institutions that address market needs or policy objectives. Thus, a government-sponsored mortgage insurer can accomplish a geographic diversification of credit risk and provide credit enhancement to facilitate institutional investment in mortgage securities. In countries where the primary market is geographically segmented, capital market investors, as well as nationwide mortgage lenders, have a major advantage in managing mortgage credit risk, the ability to diversify the risk across geographic areas.

A centralized secondary market institution (either a bond issuing facility or a conduit) can reduce the relative cost of security issues by developing economies of scale in bond issuance and liquidity in its securities. The SMI can provide guarantees of ultimate and/or timely payment of principal and interest increasing the attractiveness of the securities.

These institutions can reduce the cost of credit risk assessment, as the investor only has to underwrite the intermediary or insurer and not a large number of primary market entities or individual loans. ${ }^{11}$ In principle, they also reduce the level of the credit risk taken by investors through monitoring the primary market lenders. Such institutions may be created by the private sector but may lack the necessary credibility, particularly in underdeveloped capital markets where investors are primarily in government securities.

The government can create or sponsor an intermediary or insurer as a way to jump-start the market. In theory, a fully owned government institution is controllable with a known cost that should be budgeted. ${ }^{12}$ A disadvantage to government ownership, however, is the difficulty in many markets of finding the talent necessary to create and run the institution, particularly if government salaries are significantly below those of the private sector. Government-owned institutions may be more susceptible to political pressures that increase risk or cost. An alternative is sponsorship of a privately owned institution. An advantage to government sponsorship is the ability to attract and pay for people with

\footnotetext{
11 The fact that capital market investors may be unwilling to accept credit or agency risk does not mean that specialized government-backed institutions have to accept such risks themselves. For example, a liquidity facility that makes loans to primary market lenders and funds itself through bond issuance may guarantee its bonds against default but not accept mortgage default risk from its borrowers (i.e., by lending on an over-collateralized basis or purchasing on recourse). Alternatively it may seek re-insurance through the global capital markets. The issue is the confidence investors have in the guarantees of the institution. 12 The government can reduce its credit risk exposure and create proper incentives for lenders by requiring credit enhancement through subordination, recourse, joint and several liability, etc.
} 
the skills to create the institution, manage risk and run it efficiently. The disadvantage of government sponsorship is the inherent conflict of interest between the profit maximizing motives of management and owners and the social mission of the institution. These types of institutions can socialize the risk while privatizing the profit.

A question that policy makers need to ask is whether the government's involvement is permanent or temporary. Almost by definition, government owned or sponsored institutions are monopolies with an advantage from their government backing. The danger is that such institutions grow into economic behemoths that dominate their markets, as is the case with Fannie Mae and Freddie Mac in the US [Stanton 2002].

Guarantees: An alternative to creating a public institution is to provide guarantees for private sector security issuers to facilitate investor acceptance. ${ }^{13}$ Government guarantees of private sector issues can be targeted, removed once the market is established and can promote competition in the market if offered to all lenders. The disadvantages of guarantees are the potential for fraud and associated high agency costs of monitoring and the lack of economies of scale in securities issuance. Guarantee schemes should be actuarially priced and on the government's budget.

Market Liquidity Support: The lack of market liquidity can be a self-perpetuating impediment due to the following vicious circle: Few investors accept to buy the new securities for fear of being unable to resell them if needed. But the very absence of a wide, diversified array of investors undermines secondary trading. There are several specific ways government can help overcome this initial paralysis and improve liquidity in mortgage securities markets [Ladekarl, 2001]. These include: 1) Central bank support of a repo market by accepting mortgage securities as collateral in its repo transactions; 2) provision of guarantees that will help develop a private repo market; or 3) creation of a contingent government fund that would stand ready to buy mortgage securities in the secondary market.

Of these options, the central bank support of a repo market appears less risky than the other alternatives. If possible, it is preferable not to have the government guarantee mortgage securities and thus take on their numerous other risks for liquidity reasons. Likewise the government should not buy and hold such securities. Government also has a major disadvantage as a market maker in the potential to be adversely selected.

Investor Incentives: Governments may provide incentives to investors by exempting mortgage security interest from taxes (e.g., mortgage bonds in the Czech Republic) or reducing the capital requirements for holding them (e.g., risk weights on Fannie Mae and Freddie Mac securities held by banks are $20 \%$ as compared to $50 \%$ for whole loans). The

13 The Ginnie Mae program in the US is an example of government guarantees on securities issued by private lenders. Ginnie Mae provides a timely payment guarantee on mortgage-backed securities backed by government-insured loans issued by banks, savings institutions and mortgage companies. In emerging economies, such programs of guarantees have been implemented in Colombia since 2002. They are actuarially priced on a risk-adjusted base, and sold to potential issuers of mortgage securities (banks, securitization companies) but limited to enhance securities that refinance social housing loans. Other programs of guarantees for private MBS issuers are also being implemented by SHF in Mexico. 
risk weights may reflect a lower risk (i.e., privileged access to collateral for mortgage bonds, seniority in structured finance) or simply be an incentive to invest. While such subsidies do increase the attractiveness of the security, they are often regressive, can distort bond markets and provide incentives to mortgage lenders to just swap their mortgage loans into hold mortgage-backed-securities without leveraging the liquidity proceeds into a new production of mortgage loans (e.g., the "buy and hold" behavior observed in Colombia).

As shown in the box below, both the US and Europe have provided for special treatment for certain classes of mortgage securities that are viewed as low risk.

\section{Prudential Treatment of Mortgage Securities for institutional investors in the European Union and in the USA}

1) EU (Article 22-4 of the Units for Collective Investment in Transferable Securities) Member states may raise the ordinary limit of 5\% of UCITS assets in securities of a single issuer up to $25 \%$ in the case of bonds when (i) issued by credit institutions, (ii) subject by law to special public supervision, and (iii) legally designed to protect bondholders. Eligible are the bonds the proceeds of which are invested in assets that are capable of covering claims attached to them and that would be used, in the event of the issuer's default, on a priority basis for the repayment of the bonds.

The criteria set out by the UCITS Directive have been used for further special status granted to mortgage bonds:

- Investments of insurance companies

- $\quad$ Eligibility to the European Central Bank System repurchase transactions for monetary policy purpose in the Euro zone

- $\quad$ Reduced weighting (10\% instead of $20 \%$ ) for banks capital adequacy calculation

In addition, mortgage bonds are eligible collateral for payment systems flows in some countries.

2) USA (Secondary Mortgage Market Enhancement Act of 1984).

In 1984 the SMMEA was passed in order to promote the development of private mortgage backed securities, which was hampered by the lack of privileges accorded to "Agency" securities under many laws statutes (e.g., Employee Retirement Income Security Act of 1974, state blue sky laws regarding the primary offer and sale of securities, statutory limitations to the investment of institutional investors...). The SMMEA extended some of these privileged treatments to the highest (two top grades) private MBS backed by first mortgages on residential real estate. An important provision was the exemption from state registration requirements -, the Act preempted state laws regarding the investment of state regulated insurance companies and pension funds into qualifying mortgage-related securities, which are deemed to be equivalent to securities issued or guaranteed by the federal government. Up to then, even AAA rated MBS were not legal investment for institutional investors in more than 30 states. Also, since 1983, private MBS can be used as collateral for margin credit in inter brokerdealer securities transactions. 
Issuer Incentives: Issuers are sometimes given incentives to foster their development or encourage them to issue securities. For example, Fannie Mae and Freddie Mac do not pay state and local income tax and do not have to register their securities with the Securities and Exchange Commission, reducing issuance cost. Generally, issuer incentives are not well targeted and often captured as additional profits. The US GSE incentives are archaic for such large and profitable institutions but remain in place because of claims that they lower mortgage rates.

\section{What Has Been the Experience in Emerging Markets?}

\section{A. What Has Been Tried and Where?}

There have been many examples of individual transactions by banks or creation of institutions as securities issuers in emerging markets. These transactions range from simple mortgage bonds to complex pay through securities. There have also been a number of mortgage securities issuing institutions created in emerging markets.

\begin{tabular}{|c|c|c|c|c|}
\hline Mortgage Bonds & $\begin{array}{l}\text { Pass- } \\
\text { Through } \\
\text { Securities }\end{array}$ & \begin{tabular}{|l} 
Structured \\
Finance
\end{tabular} & Conduits & \begin{tabular}{|l} 
Liquidity \\
Facilities
\end{tabular} \\
\hline $\begin{array}{l}\text { Chile } \\
\text { Colombia } \\
\text { Poland } \\
\text { Czech Republic } \\
\text { Hungary } \\
\text { Bulgaria }\end{array}$ & Hong Kong & $\begin{array}{l}\text { Colombia } \\
\text { Argentina } \\
\text { Chile } \\
\text { Mexico } \\
\text { South Africa } \\
\text { Korea } \\
\text { Philippines } \\
\text { Trinidad } \\
\text { Panama } \\
\text { India }\end{array}$ & $\begin{array}{l}\text { Argentina } \\
\text { Brazil } \\
\text { Colombia } \\
\text { Hong Kong } \\
\text { Korea } \\
\text { Thailand }\end{array}$ & $\begin{array}{l}\text { Malaysia } \\
\text { Trinidad } \\
\text { South Africa } \\
\text { India } \\
\text { Jordan }\end{array}$ \\
\hline
\end{tabular}

While there are interesting stories to tell in each country, we have selected several for discussion as representing various approaches to developing capital market finance. 


\section{B. Case Studies}

\section{Latin America \\ a) Argentina}

Banco Hipotecario $(\mathrm{BH})$ is the former state housing bank of Argentina. It has been a pioneer in the issuance of mortgage-backed securities in Latin America. BH is a partially government-owned bank with budgetary and administrative autonomy. Its retail funding operations were suspended in 1990 in the aftermath of the hyper-inflation and it was rechartered and restructured as a wholesale bank providing medium and long term financing for construction and home loans. The bank was partially privatized in 1997 and resumed retail operations soon thereafter. BN issued its first mortgage-backed securities in October 1996 with 4 additional transactions through February 2001 totaling more than $\$ 615$ million. $^{14}$

BH worked with the government to enact a securitization law in 1996 that created the framework for domestic issuance. However, it ultimately chose to issue most of its securities internationally in order to tap new funding sources.

Initially a wholly-owned government bank and after 1999 a partially privatized institution, BH's issues were not guaranteed by the government. The typical structure was a senior-subordinated collateralized mortgage obligation with additional credit enhancement from a reserve fund and excess spread account. The BH transactions were notable in several respects: 1) they were sold in the US proving that securities backed by Argentine mortgages could attract international investors without government backing: ${ }^{15}$ 2) they broke the sovereign ceiling showing that structuring could deliver higher ratings than the country of collateral origin; and 3) the BHN IV issue was the first MBS to carry political risk insurance provided by Zurich US [Zurich 2000].

Although expensive in terms of yield and degree of credit enhancement, $\mathrm{BH}$ regarded the program as a successful way to raise funds. As the leading mortgage originator in Argentina, it had a demand for funds that far outstripped its retail funding capabilities. The lack of a long term bond market in Argentina led BN to issue most of the bonds internationally.

The events subsequent to the Argentine government default and devaluation have been quite adverse for these securities. ${ }^{16}$ Argentina's default and soon-to-follow devaluation were accompanied by a variety of unorthodox measures designed to cushion the blow of the devaluation to the system. According to Fitch Ratings, the effects of the initial devaluation could have been absorbed by the credit enhancement within the structure;

\footnotetext{
${ }^{14}$ Banco Hipotecario, 2002. The last issue was by Banco de Crédito y Securitización S.A. (BACS), a joint venture between BN, its controlling shareholder IRSA Inversiones y Representaciones SA and the IFC. All the mortgages backing the BACS transaction were purchased from BN.

15 The international dimension of BH's issues has to be put into perspective by the fact that, although denominated in US dollars, they were in part targeting Argentinean investors with dollar holdings (the securities were governed by Argentinean law)

16 Fitch Ratings 2002.
} 
however, the immediate pesofication of the mortgages proved to be devastating. Similar to all Argentine financial institution assets, the payment terms of the underlying mortgage were re-denominated into pesos. It caused an immediate peso-dollar mismatch for these transactions. Credit enhancement declined by $30 \%$ overnight and then by more than $50 \%$ once the peso floated freely.

The final blow was the pesofication of the rated bonds. The debt payments made to investors were below the dollar amount necessary to meet timely payments of interest on the original terms and the securities were downgraded to 'D.' In addition, their performance was impacted by mandatory delays within the foreclosure process of 180 days and transfer and convertibility restrictions on the payments of principal.

BHN IV and BACS transactions included political risk insurance for the interest payments. However, the transfer and convertibility protection insurance provided no protection to investors against legal risks and the potential for a deterioration in credit quality due to government actions.

\section{b) Chilean mortgage bonds}

The way mortgage bonds became both the main housing finance vehicle and a major instrument of the capital market is a textbook case of coordination and sequencing of interrelated policy measures.

The Chilean mortgage bond system was borne out of a financial crisis in which the primary mortgage lenders, the Banco del Estado and a network of Savings and Loans (SINAPS) collapsed due to a massive deposit run in 1976/1977- the first casualties of the ill-controlled deregulation that was a major reason of the general financial crisis in 1982.

To collect capital for housing in lieu of the defunct savings deposit based system, an old debt instrument was re-activated: the "Letras de Credito Hipotecario", the actual usage of which had been abandoned in the 1930s crisis. This time, letras were directly conceived as an indexed bond, able to keep the real value of invested capital - although they legally may be denominated in Pesos. The indexation mechanism had been renovated in 1967 with the creation of a new index, the "Unitad de Fomento" (UF) that had become a widely recognized and accepted account unit.

From the outset, $\mathrm{LCH}$ were denominated in UF. This was the first step of a well balanced sequence of financial policy decisions. Absent a significant capital market at that time, the government provided in an initial phase the bulk of required investment, through a dedicated credit facility of the Central Bank. This facility lasted until 1980. At the end of 1980, a major reform was introduced: the creation of a fully funded pension system based on mandatory contributions of wage earners to individual retirement accounts. As a derivative of this system, life insurance companies also developed to sell annuities to the 
retirees. Pension funds grew to represent about 55\% of the GDP, and life insurance companies $17 \%$, by 2000 .

This development was the main driver of the expansion of $\mathrm{LCH}$ and the extension of their maturity to 25 years. Although there are no guidelines that expressly direct institutional investors to purchase letras - other than a high global ceiling of $50 \%$ of the portfolio in the case of pension funds - they were de facto strongly induced to do so by the lack of alternative vehicles: with $\mathrm{LCH}$, an appropriate tool was available to address the particular requirements of pension fund management. Specifically,

- Pension Funds were only invest in tradable securities and were barred to buy stocks until 1985

- Government budget has regularly shown surpluses in Chile - its balance has stayed positive since 1986 with an exception of 1999

- Securities bought by institutional investors must be rated by at least two agencies.

Therefore, although LCH share in pension funds portfolios has been declining from about $50 \%$ in 1985 to less than $15 \%$ recently, the continuous growth of pension funds, which hold more than half of the outstanding letras (life insurance companies about $12 \%$ ) has resulted in the deepening of the letras market. Today approximately 70 percent of mortgage funding comes from the letras market. For more detail on the Chilean mortgage bonds see Hassler, 2002.

\section{c) Colombia}

Titularizadora Colombiana (TC) was created in July 2001 as a securitization company. According to the December 1999 law that reformed the overall housing finance system in crisis, such companies may be created as non-credit institutions to securitize housing loans. Their main purpose is to raise long-term funds from the capital markets, manage the significant cash flow risks of mortgages and provide equity relief to the primary mortgage lenders. TC is regulated and supervised by the Securities Commission. Its capitalization (Peso 70 trillion e.g. USD 25 million) came from private investors including the dominant mortgage lending banks and the International Finance Corporation. The company receives no explicit or implicit support from the government. In the past, some banks had also individually issued MBS but the TC can perform this function under better conditions of size, liquidity, risk management and specialization.

TC was created in response to the severe crisis to which the mortgage markets have been exposed since 1998. Specialized savings and loans and borrowers were hit by interest rate shocks, rising unemployment and depressed housing prices. The situation was worsened by a risky system of indexed credit products, and a culture of non-payment fueled by a judiciary reaction against lenders. Despite several policy and regulatory measures, the industry has not been fully restored to soundness. ${ }^{17}$ The ex-savings and loans turned into

\footnotetext{
${ }^{17}$ More than $20 \%$ of the portfolio is still non-performing, although provisioning and prudential capital has been steadily rising.
} 
commercial banks remain vulnerable to market and credit risks. In that context, the issuance of mortgage securities has been an immediate operational priority to improve this distressed sector.

Within its first two years, the company issued four securities ("TIPs") for a total of Peso 1.82 trillion ( $\$ 650$ million) or $13 \%$ of the outstanding residential mortgage debt. TC aims to reach a $38 \%$ market share by the end of 2006 . Most private and public mortgage lending institutions have already used TC to securitize part of their mortgage portfolios. TIPs are structured with senior and subordinated tranches. Senior tranches are designed to receive a domestic AAA external rating thanks to a combination of internal credit enhancement (junior tranches, reserve fund) and external through guarantees sold by IFC and the state (for securitized social housing loans).

So far, TC has not been providing its own institutional guarantee to the senior securities but has been holding a small amount of subordinated tranches. Investors can opt for various maturities (mostly 5, 10, 15 years). The loans and securities are UVR-indexed fixed real rate credits. Its first issues were backed by well-performing, low LTV seasoned housing loans. The performance of pools has been good but prepayment rates are high. The interest of domestic bond market investors for such MBS has been growing.

A public agency - Fogafin - has been managing since 2002 a fund that sells to issuers a guarantee for the full timely payment of eligible mortgage securities (both MBS and mortgage bonds) issued by banks, fiduciaries, and securitization companies, provided that they fund only social housing credits (VIS loans). The quality of securities is then enhanced to the level of public debt thus reducing the funding cost of VIS loans that are capped by law at UVR $+11 \%$. FOGAFIN has developed eligibility standards and charges an actuarially-based premium. The fund has access to budgetary support (US\$200 million) if needed. This program is expected to be temporary.

Eligible mortgage securities can be repo'd at the Central Bank with haircuts through a public fund (FRECH) managed by the central bank. The function of FRECH is to increase liquidity in the capital markets. New capital adequacy rules will soon be implemented for banks holding mortgage loans or various tranches of mortgage securities according to the actual exposure to risk, as well as to the securitization company to avoid any possible capital arbitrage. The TC has been preparing a new MBS specially structured to securitize non-performing mortgage loans.

The securitization companies are aided by a large income tax exemption granted to all MBS investors (for securities issued until 2006). This regressive subsidy artificially reduces the cost of funds through securitization. TIP yields show negative spreads by 200-300 basis points but at a considerable fiscal cost without any social targeting. This feature has also led some banks to just buy and hold MBS for tax arbitrage, and may more generally distort the development of fixed income markets. TC has been active trying to diversify its range of institutional investors to various mutual and investment funds, but has not yet actually mobilized the long-term savings of pension funds that cannot capture this tax benefit. 
The housing finance law and subsequent regulations have also allowed banks to directly issue mortgage bonds. These are bonds issued by banks using general mortgage pools as collateral (through a privilege over the bank's bankruptcy over a determined cover pool of eligible assets). This type of secure and on balance sheet funding tool has been tried only once to refinance new mortgage loans, and could be further developed.

\section{Asia}

\section{a) Korea}

The Korea Mortgage Corporation (KoMoCo) was set up as a joint venture by the Ministry of Construction and Transportation (MOCT), the Housing and Construction Bank, Kookmin Bank, Korea Exchange Bank and Samsung Life Insurance Co. at the end of 1999. In 2000, the International Finance Corporation (IFC) and Merrill Lynch became foreign investors in KoMoCo. Along with the equity investment, these foreign investors brought technical assistance to KoMoCo from Countrywide International Consulting Services and Fannie Mae in the areas of business, operations and technology development.

KoMoCo's mission was to securitize the National Housing Fund (NHF) loans as well as private sector mortgages originated by commercial banks and other special finance companies. KoMoCo's bonds are not guaranteed by the Korean government, but are still considered a safe instrument due to the government involvement (i.e., an implicit guarantee).

Komoco has completed 9 transactions, 7 collateralized by NHF loans1 1 collateralized by Samsung Insurance loans and one collateralized by National Agricultural Cooperative Federation loans, bringing total securities issued to more than 3 trillion won ( $\$ 2.5$ billion) through August-2003 [www.komoco.co.kr]. The non-NHF securities represent only $1.1 \%$ of total issuance. KoMoCo's securities are structured as callable and non-callable bonds with senior and subordinated tranches. The structure of KoMoCo's MBS deals is shown below.

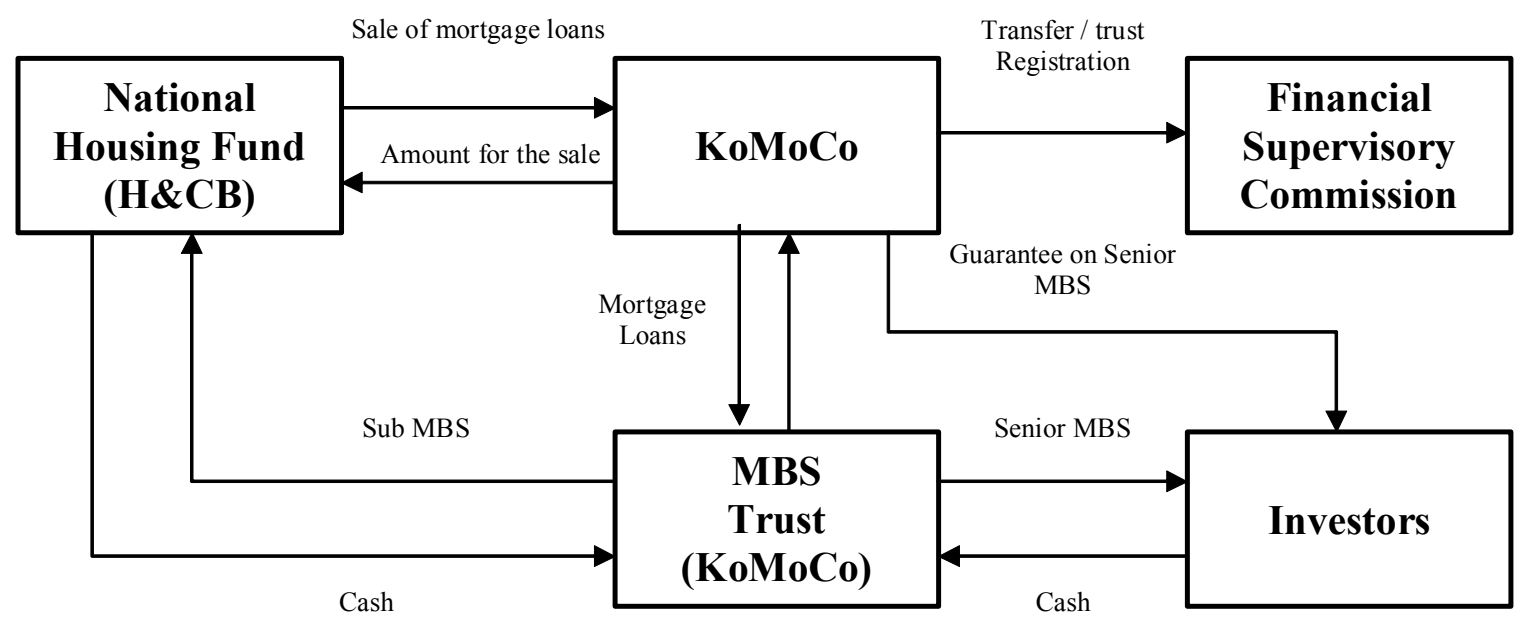


The bonds are not true pass-throughs and the government retains the credit risk through purchase of the subordinate bonds by the NHF. KoMoCo holds the junior bonds on the NACF loans and Samsung purchased the junior bonds on its transaction. Komoco has been successful in extending the maturity of fixed income securities in the Korean market. Komoco has issued bonds with a maturity of 15 years and 59\% of its MBS are long-term securities with a maturity of more than five years, and $78 \%$ are those with a maturity of more than three years [You 2004].

To date KoMoCo has not been a commercial success, however, in large part because there is no demand for wholesale funds in the Korean market. The mortgage market is dominated by Kookmin Bank and the NHF, which account for over $85 \%$ of mortgage debt outstanding. The NHF loans are subsidized and the government absorbs the yield difference between the mortgages and bonds through its subordinate security. Kookmin is a large, liquid bank that does not need wholesale funding - which is true for the other large banks in Korea as well. KoMoCo could provide a funding outlet for small mortgage companies but is hampered by a restriction against holding loans on its balance sheet or purchasing loans from lenders without an extensive performance history.

In order to stimulate the development of the MBS market, the Korean government made a number of significant changes to the market in 2002 [You 2004]. The MBS Company Act was amended to extend the payment guarantee limit to 30 times (from 20 times) equity capital and a BIS risk weight of $20 \%$ now applies to MBS issued in accordance with the Act. Lower taxation now applies to interest and dividends from MBS. In addition, securitized loans are exempted from acquisition and registration taxes. Furthermore, interest on long-term mortgage loans of more than 10 years is tax deductible.

The government also decided to restructure Komoco from a private corporation to a government-owned agency at the end of 2003. The new entity, the Korean National Mortgage Corporation, will be wholly owned by the government and have greater powers than Komoco, including the ability to hold loans on its balance sheet to form larger MBS pools. A major reason for the change is to improve the funding cost through securitization as an incentive for lenders to make longer term loans (the maturity profile of Korean mortgages has shortened considerably in recent years).

\section{b) Hong Kong}

The Hong Kong Mortgage Corporation [HKMC] was established in March 1997 to reduce real estate asset concentration in the banking system in Hong Kong and to stimulate the development of a mortgage capital market. Since 1998, the size of its retained mortgage portfolio has grown at an annual compound rate of $25.6 \%$ to the current amount of $\mathrm{HK} \$ 28.3$ billion [ $\$ 3.6$ billion], which is close to $5 \%$ of the residential mortgage loan market [HKMC Annual Report 2002]. 
HKMC was designed to operate as a conduit, purchasing mortgages from qualified lenders funded through the issuance of pass-through MBS. To date, most of its funding has come through corporate bond (discount and medium term notes) issuance with the loans remaining on its balance sheet. At the end of December 2002, the Corporation had 73 issues of debt securities outstanding. The outstanding amount of HK\$28.6 billion accounts for $7 \%$ of the market other than the Exchange Fund Bills and Notes. The corporation issues MBS as part of a "back-to-back" program in which lenders exchange pools of mortgage loans for HKMC-guaranteed pass-throughs, thus obtaining regulatory capital relief $(50 \%$ to $20 \%)$.

HKMC has expanded the variety of instruments in the Hong Kong capital market. It has successfully introduced long term MBS, a reverse floating rate bond, a CMO and multicurrency bonds in the Hong Kong bond market. However, it has not been successful in establishing a deep MBS market, in large part due to the short term bias of Hong Kong's institutional investors and the increased liquidity of the banking system.

HKMC has been impacted by the turn down of the HK economy since the onset of the Asian financial crisis. The commercial banks have been reluctant to sell mortgages to HKMC for two reasons: excess liquidity makes wholesale funding unnecessary and the banks have used this liquidity to engage in a price war for retail mortgages, making wholesale funding unattractive economically. In order to address this problem, the Corporation decided in December 2000 to expand the scope of Approved Sellers to include Government housing agencies, other public bodies and property developers. Successful execution of this strategy enabled the HKMC to achieve a record mortgage purchase amount of $\mathrm{HK} \$ 14.4$ billion in 2002, exceeding both the HK\$13.2 billion achieved in 2001 and the target of HK\$13.5 billion set for 2002. These activities, however, mean that HKMC has become primarily a government funding mechanism as opposed to a catalyst for private mortgage capital market development.

HKMC has pioneered the introduction of mortgage insurance to the Hong Kong market, thus performing a role as a catalyst for innovation. In 2002, 9 percent of new loans carried mortgage insurance. The mortgage insurance program is offered by the HKMC and re-insured by private mortgage insurance companies (United Guaranty Insurance and PMI Mortgage Insurance). The program has facilitated an increase in maximum LTVs (up to 90\%) and average loan size. The newly created HOME Program addresses the problem of negative equity in Hong Kong. It provides insurance to cover losses in excess of $90 \%$ and up to $140 \%$ of the value of the property, allowing banks to convert a negative equity mortgage into a positive equity mortgage. The HKMC, as the primary insurer, disperses the credit exposure through reinsurance arrangement, backed by the issuance of credit-linked notes. 


\section{c) Malaysia}

Cagamas Berhad was created in 1987 following a recession and liquidity crunch that restricted credit for housing, particularly for moderate income households. The purpose of Cagamas was to provide more liquidity to mortgage lenders, reduce market risks, assist social housing finance, sustain construction sector, and develop private fixedincome markets.

Cagamas purchases mortgage loans (the principal balance outstanding) from mortgage originators, with full recourse to the primary lenders, at a fixed or floating rate for 3 to 7 years. This is in effect a secured financing with Cagamas looking first to the credit of the financial institutions when mortgage loans default. Cagamas issues debt securities to investors, in the form of fixed or floating rate bonds, Cagamas notes, or Cagamas Mudharabah (Islamic) Bonds. The debt is amortized independently of the mortgages.

Cagamas is the largest non-government issuer of debt in Malaysia. Its securities are rated AAA by the Malaysian Rating Agency and subject to only a $10 \%$ risk weight for bank investors. As of the end of 2002, Cagamas had outstanding debt securities exceeding 24.9 billion Ringgit (approximately $\$ 6.6$ billion) [Cagamas Berhad 2002].

As a liquidity facility, Cagamas' market share fluctuates with market conditions. At the peak in 1997 at the height of the Asian financial crisis it financed 41\% of new mortgages. The market share has fallen sharply to $18 \%$ as banks became more liquid and asset short.

Twenty percent of Cagamas' shares are owned by the Central Bank with 74 commercial banks and finance companies holding the remaining shares. The Deputy Chairman of the Central Bank chairs the Cagamas Board. Cagamas has been profitable throughout its existence with return on equity in the mid-to late 1990s exceeding $30 \%$. Its ROE has dropped sharply in recent years and was 13.6\% in 2002 reflecting the fall in assets and margin.

Cagamas has successfully pioneered a number of products in the market including fixed and variable rate, longer maturities, recourse and non-recourse, Islamic debt, and leasing/commercial property lending. It expects to begin purchasing loans without recourse and issuing pass-through securities in the near future, but this next stage of development has been encountering difficulties mostly caused by the reluctance of liquid primary lending institutions to sell their most profitable mortgage assets, and recent increased capacity to proceed directly with their own securitization.

Cagamas receives a number of significant privileges from the Malaysian government, without which its refinancing activities would not have been perceived as sufficiently attractive for primary lenders. Loans sold to Cagamas are not subject to the Central Bank reserve requirements. Its securities are eligible as liquid assets (banks and finance companies must keep an additional $10 \%$ of assets in liquid form). Cagamas securities carry a risk weighting of $10 \%$, compared with a $50 \%$ rating for housing loans, for investing credit institutions. 


\section{E. Europe and the Middle East}

a) Hungary

A legal framework for mortgage bonds was created by a June 1997 Act. Mortgage lending has been expanding extremely rapidly since then, and the usage of mortgage bonds followed pace. By June 30, 2003, the residential mortgage loans outstanding amount reached $€ 4.2$ Bln (housing finance grew from 1.3 \% GDP in 1998 to $6.6 \%$ in 2002), and the volume of mortgage bonds reached $€ 1.9 \mathrm{Bln}$.

The main features of the framework are as follows:

- Mortgage bonds can only be issued by mortgage banks, the business of which is narrowly specialized.

- The quality of collateralized portfolios is achieved through a classical set of provisions: loan-to-value ratio for loans funded through mortgage bonds limited to $60 \%$ (absolute limit for each loan of $70 \%$ ), valuation rules, strengthened mortgage rights enforcement, cover principle evidenced by a cover register, possibility of substitute collateral but only on government credit and within a $20 \%$ limit, special supervision and existence of an asset supervisor trustee.

- Mortgage bondholders can execute forced sale of the cover assets. In bankruptcy proceedings, if their claims are not entirely covered by the collateral, they will have a "super- priority" that makes them supersede unsecured creditors on other assets until the deficiency is compensated.

- Mortgage banks may exclude the early repayment of the loans by the mortgagors.

There are three mortgage banks and the main one, FHB bank is state owned. They are direct lenders and can also refinance commercial banks engaged in this line of business. They are induced to do so by a generous - even after an adjustment downwards in June 2003 - subsidy scheme that benefits loans funded by mortgage bonds. This scheme results in low lending rates for loans under $€ 380,000$ at $5 \%$ or $6 \%$, lower than the Treasury bond yield of around $7 \%$, by subsidizing the cost of funding, and, at the same time, ensuring large intermediation margins to the participating institutions. Furthermore, the effective yield on mortgage bonds is lowered by an exemption of the withholding tax $(15 \%)$ to which holders of other bonds, including government paper, are subject. This scheme come on top of other housing assistance systems, including a direct demand subsidy and income tax relief for interest paid on mortgage loans.

This accumulation of government assistance is neither efficient nor sustainable. The subsidy is not targeted and does not leverage private sector spending or other government programs. Artificially lowering interest rates is a sure recipe for stunting the provision of finance by the private sector, which in its turn is susceptible of lobbying for additional government support, until the strain on public finance compels a reversal in the spending policy without having established substitute financial sources. 


\section{b) Jordan}

The Government of Jordan with support of World Bank implemented a liquidity facility. the Jordan Mortgage Refinance Company - or JMRC - in 1997 to provide funding solutions to the liquidity and market risks of commercial banks entering housing finance. The institution was created to replace a subsidized Housing Bank. This latter's law was amended to create a level playing field in housing finance for all banks.

Banks may obtain fixed-rate term (generally between 3 and 5 years) loans from JMRC (that can be automatically re-priced, renewed to minimize the liquidity risk arising from longer maturity mortgage loans). The loans are over collateralized. As collateral, banks pledge underlying mortgages that must meet JMRC's prudential eligibility standards, including a maximum loan-to-value ratio of $80 \%$. JMRC's funds came from (i) an initial subordinated line of credit from the World Bank, and (ii) mostly the issuance of domestic bonds. JMRC has been instrumental in expanding the range of fixed-income securities in Jordan, as a regular issuer of simple, secure and attractive private bonds for banks and institutional investors. Its larger and centralized issuance function has permitted a greater number of newly competing mortgage lenders to access sustainable funding resources from bond markets.

The JMRC is a financial company with a mixed capital composition including several private banks, the Central Bank of Jordan, the Social Security Corporation, and the Housing and Urban Development Corporation. It has not yet fully addressed the resulting issues of corporate governance and implicit government sponsorship.

At the end of 2002, JMRC had outstanding refinance loans to banks of nearly JD 57 million representing over $30 \%$ of all eligible mortgage loans. JMRC had outstanding bonds of approximately JD 53 million (US\$ 37.8 million), whose original yields were between 100 and 200 basis points below other corporate bonds, reflecting the view by investors that JMRC bonds are highly secure and treated as such through investment regulations (low risk-weighting, eligible as reserves).

JMRC's recent operations have slowed as in a declining-rate environment banks tend to rely on alternative variable-rate sources of funds, knowing that if for some reason they should need more liquidity, they can turn back to JMRC. This latter has been playing a catalyst role as of an accessible source of refinancing that gives banks a level of comfort to enter the housing finance arena.

The stock of market-rate mortgage loans increased from JD 100 million in 1997 to JD 336 million at end 2001. The number of lenders active in mortgage lending has increased to ten. Banks require smaller down payments from borrowers (as low as $20 \%$ or $10 \%$ compared to $50 \%$ or more before). Several lenders have made arrangements with developers to provide financing to end purchasers. Maturities of housing loans have more than doubled and are now generally between 12 and 15 years, with some lenders offering up to 20 years. Mortgage rates have declined from $14 \%-15 \%$ down to $9 \%-10 \%$. In addition, JMRC plays an essential funding role to leverage a targeted and fiscally 
sustainable program of interest rate subsidies (also note the end of the housing bank subsidies). All these changes have greatly improved the affordability of housing loans.

The next challenge relates to further improving the accessibility of housing finance services to lower-middle income households. This implies developing loans with fixed rates for a longer period of time, the placement of longer-term bonds, the creation of a refinancing window for Islamic housing debt, improvement of the various subsidies schemes, and the development of securitization along with better credit risk management tools (including improved mortgage insurance products, strengthened foreclosure proceedings, and credit information systems).

\section{Where Are the Successes? 1. What constitutes success?}

In our view, success requires repeat issuance of standardized securities, a significant share of funding for housing coming from the capital market and secondary trading in security instruments. Only with sustained issuance will the benefits of improved accessibility and affordability of housing finance be realized. Repeat issuance is necessary to improve investor acceptance, bringing new investors to the market and lowering liquidity premiums. It can reduce and spread the one off transactions cost of security issuance over a broader base and obtain the interest of market makers, regulators, rating agencies and other entities that can spur market development.

Another measure of success is whether the introduction of a new instrument and/or institution produces a significant and positive change in the finance of housing within a country. For example, if the introduction of a facility brings new lenders in the market and increases the supply of funds it may be judged a success even if its volume of business is modest. If introduction of mortgage securities improves the structure of loans, by lengthening the term or increasing the LTV, it may also be judged a success.

A successful mortgage capital market will also feature carefully tailored and targeted government support. A large volume of issuance reflecting an excessive subsidy or unmanageable risk exposure for the government should not be viewed as a success.

\section{Examples of success}

By our criteria there are two solid examples of successful introduction of mortgage securities in emerging markets: Mortgage Bonds in Chile and bond issuance by Cagamas in Malaysia. There are also several promising recent developments (Colombia, Jordan) that if sustained will also constitute a success. ${ }^{18}$

18 Although not reviewed in this paper, the The Home Mortgage Bank of Trinidad (HMB) may also be considered a success. HMB was created in 1985 along similar lines as Cagamas. It has a similar structure 
In both cases of success, there has been sustained issuance of mortgage securities and they finance a significant part of the mortgage market (20\% in Malaysia, $70 \%$ in Chile). Chilean mortgage bonds are the major fixed income instrument and enjoy widespread acceptance without having ever received government guarantees. Cagamas has been successful in getting new lenders into the market and lengthening the term of mortgage loans. Cagamas has pioneered the securities funding of Islamic loans, which may be a role model in Jordan and other Islamic countries. Cagamas has been profitable throughout its existence and has successfully weathered a severe turndown in the domestic economy and property market.

Both Cagamas and Chilean lenders issue bonds, and the development of their lending activity did not require more complex mortgage security structures. ${ }^{19}$ Cagamas issues "agency" debt, unsecured obligations of the corporation but in effect backed by their mortgage loan portfolios. Chilean mortgage bonds are general obligations of the issuer backed by preferential access to the collateral. As "pass-through" structures they are more complex than straight debt but considerably simpler than most mortgage securities. These results suggest that simpler structures may be more likely to be successful than the more complicated securitization models in emerging markets.

The role of the government has been important in the relative success of these initiatives. Both Chile and Malaysia have strong legal and regulatory systems - a necessary prerequisite for success as noted above. Chile is an important example of a limited role of government. The government provided liquidity support for the market upon its creation but ended the support once the market was established. It provides regulatory oversight of the market and investors but there are no subsidies or unusual treatment of the bonds for issuers or investors. The government is a minority owner of Cagamas. It puts up a portion of the initial equity, providing comfort for private sector investors. This support gives the institution a small funding advantage as the government is either implicitly guaranteeing the securities. A strong central bank board presence keeps the institution focused on its public policy objectives. Cagamas' loans and the bonds also receive favored regulatory treatment

Government ownership has drawbacks as well. Even if the government is a minority shareholder it wields majority influence when it comes to public policy initiatives. This can lead to inappropriate lending programs or investment as is the case with many housing banks. This may be evident in the shift of HKMC towards the finance of government-originated loans - a development that bears watching. Cagamas is also a monopoly provider of service. After nearly 20 years of successful operation it may be that the institution could be privatized (without its regulatory advantages) or phased out in favor of direct lender bond issuance.

and pre-requisites as Cagamas. Recently it evolved through MBS issuance and introduction of primary mortgage insurance. The recent issuance of MBS in Morocco appears as well to be very promising.

${ }^{19}$ Securitization has taken off in Chile in the last couple of years, but mostly as a natural evolution of "Mutuos Hipotecarios Endosables " carried out by specialized originators. 
Two other institutions, JRMC (Jordan) and TC (Colombia), have had promising beginnings but it is too early to judge them to be successful. They have both have funded a substantial portion of the outstanding mortgage debt [30\% and $13 \%$ respectively]. However, in the case of Jordan, the amounts are still small and in the case of Colombia the issues represent a crisis-induced restructuring of existing balance sheets and not new lending. JRMC has encouraged more banks to lend and facilitated a lengthening of loan maturities. The test for both will be whether they can sustain their initial success. TC will be successful if it can continue purchasing and securitizing loans after removal of the significant tax subsidy.

By some criteria, Argentina could be considered a success. BN was successful in tapping of international markets, though less so the domestic market and showed how structuring could improve the marketability of mortgage loans. However, BN only concluded 5 transactions before the devaluation crisis and therefore did not have the opportunity to show that it was a sustainable model. Although BN securities were not guaranteed by the government it was exempt from the gross proceeds tax on the sale of mortgages. Its experience demonstrates the risks of hard currency funding/lending.

HKMC may be considered by some a success reflecting its creation of a mortgagebacked securities market and introduction of mortgage insurance. Commercial banks had issued MBS prior to the creation of HKMC. The rationale for creation of HKMC was concern over the concentration of real estate loans on bank balance sheets and the desire for standardization and liquidity in the market. In order to provide a competitive alternative to on-balance sheet funding, it was deemed necessary for HKMC to have a government guarantee. The Asian financial crisis undermined the policy rationale and the large banks have questioned the on-going need for a government-backed conduit. HKMC has not purchased loans from smaller mortgage companies, citing their lack of experience, and thus has not stimulated very much competition in the market. It has turned to purchase of government agency originated loans and loans originated by developers. For the former category it functions mainly as a funding arm for the government, like KoMoCo. For the latter it is arguably displacing (more expensive) private sector credit.

HKMC has introduced mortgage insurance with US private mortgage insurers currently providing reinsurance. However, the structure of the program appears counterintuitive. The Hong Kong property market is large relative to the size of the economy and strongly influenced by public policy (e.g., public land sales). A proper public policy function should be to provide systemic risk reinsurance for private mortgage insurers.

There have been numerous less successful attempts at developing mortgage capital markets as well. Many fail to generate an on-going flow of business [e.g., securities issued by Colombia CAVs, Cibrasec in Brazil, Agency for Mortgage Finance in Russia, Secondary Mortgage Corp. in Thailand, MBS issued by Philippine banks] and cannot be regarded as successful (from a business perspective), at least to date. There are various reasons for this lack of success including lack of investor acceptance, weak legal/regulatory framework, overly expensive funding option. All the cases listed above 
have tried more complex security designs, usually pay-through structures. These instruments may be too complex for the markets in which they were introduced. There are a number of countries still in a take off phase, including India, Mexico and South Africa. In these cases, there have been pilot issues after many long years of development. It remains to be seen whether they will be successful.

\section{Conclusions}

\section{1) Lessons Learned}

\section{a) You can't skip the basics}

A country must have a sufficient legal, regulatory and primary market infrastructure in place before mortgage securities will take hold. A good framework is a necessary not a sufficient condition.

The sheer difficulty of developing infrastructure is one reason why there has been only limited success in introducing mortgage securities in emerging markets. The legal and regulatory complexities of mortgage securities and specialized institutions are formidable even in sophisticated developed economies (e.g., the Germans still don't have the right tax structure). It is the case that many pieces of the puzzle have to be put into place before a picture emerges and in a number of countries, the introduction of mortgage securities is still a work in progress.

It would be easy if setting up an appropriate legal and regulatory framework were sufficient to establish a market. This is far from being the case. Many countries have devised a framework for securitization or mortgage bonds, but the time lapse between the creation of the legal infrastructure and the actual development of regular issues can be very long - between 4 and 10 years. The development of a satisfactory legal framework for mortgage securities is also often complex and time consuming (often requiring further amendments), notably in civil code legislative environments where the concept of a trust may be missing as a convenient, flexible and bankruptcy-remote special vehicle to issue mortgage backed securities.

In rare cases, technical flaws in the framework explain the difficulty (ex: Chile's securitization law in 1999 where SPVs had to buy portfolios before issuing securities). More often, exogenous obstacles stunt the actual use of a framework, however well designed. For instance, in Poland the length of the lien registration process - up to two years in some jurisdictions and the courts in charge of the registration in the land book are overloaded and appear to be a strong impediment to the issue of mortgage bonds. ${ }^{20}$ In

\footnotetext{
20 From 2000, when mortgage banks started operating, and 2002 only $\$ 60$ million were issued.
} 
India, the extension of securitization is hindered by the level of stamp duties on the assignment of financial assets (between $3 \%$ and $14 \%$ in many states).

The most difficult obstacles to overcome are often the ones that are anchored in market conditions. For MBS, a major hindrance is the lack of a "market" for credit risk. In most emerging economies, there are no insurers, or guarantors nor investors ready to take over the risk from the lenders. In this case, MBS sellers must use internal credit enhancement tools, which are necessarily very expensive if high ratings are sought. Also in the case of pass-through instruments, there are often few investors willing to buy the prepayment options embedded in the loans, which are very difficult to value in the absence of historical data and uncertainties about the borrowers' behavior. ${ }^{21}$ In many emerging markets, it is still difficult to lay off cash flow risk. Investors will not accept long-term instruments or prepayment risk. Many issuers and investors do not have the necessary systems and capabilities to manage amortization and prepayment.

A simple and fundamental factor that can suspend the growth of mortgage securities is the lack of development of the primary market itself. Although the lack of long term funding is an issue that can impede development, the growth path starts with the lending activity - even in the case of specialized institutions, created to remedy the lack of interest of commercial banks. ${ }^{22}$ For various reasons - the building up of a portfolio, name recognition, time needed to arrange issues, and in the case of securitization high issuance expenses - the volume of loans must first reach a critical mass before making efficient use of capital market instruments. It is unrealistic to expect to issue mortgage securities as long as overall market lending remains below a certain threshold.

\section{b) There must be a market demand}

Potential issuers in many countries have not perceived a need for creating or issuing mortgage securities. The need for securitization has been low, as capital ratios have been improving in most countries, implying less need for off-balance sheet finance. Today, most depositories are liquid and not in need of significant new sources of funds. In most markets, deposit funding is significantly cheaper than capital market funding providing a further obstacle to capital market funding.

The structure of mortgage markets is also an obstacle in some countries. If a market is dominated by a few large, liquid depository institutions, it will be difficult to create a successful mortgage securities market. The large lenders, who may ration mortgage

\footnotetext{
21 The acceptance of the prepayment option on the Chilean mortgage bonds has a high price: the option is valued as a pure financial call, although it cannot be exercised independently from the repayments of the loans, and despite a low propensity of borrowers to actually take advantage of the prepayment facility. ${ }^{22}$ It is a basic rule that specialized institutions rely on capital market for their funding, but at the start of their activity they typically use their equity and/or bridge financing from banks before tapping the capital market. The lack of bridge funding as slowed development of a private secondary market in Korea. Specialist mortgage companies have entered the market and successfully issued mortgage pay through securities. They have been very small scale and thus expensive, however. The mortgage companies have not been able to get significant amounts of reasonably priced warehouse funding limited their ability to aggregate loans for larger pools
} 
funds, do not need the funding and can price new competitors using wholesale funding out of the market. These lenders do not need mortgage securities to manage cash flow risk either as their main mortgage instrument is an ARM that can match funds with deposits.

There must also be a demand for such securities by investors. In part this is an infrastructure issue. They must have the authority to invest and be able to realize the benefits of a low risk investment through risk based capital treatment, reserve eligibility etc. In addition, investors must understand and be able to manage the complex risks of mortgage securities. This requires a combination of disclosure and education at the least. Importantly it requires a commitment on the part of issuers for regular issuance, as liquidity is a major characteristic in demand by investors. Government must play a role by leaving sufficient space for issuance. Excessive government debt issuance crowds out mortgage securities and does not give them a chance to take hold.

\section{c) Simple may be better than complex}

It is notable by our measure of success that simpler instruments and institutional designs have been more successful. Some of most successful examples of mortgage capital market development came from bond issuance. These instruments are relatively simple with credit enhancement from the balance sheet of the issuer. The more successful institution designs have been liquidity facilities rather than conduits.

It is a simple fact that there are limits to the complexity that can be imposed on emerging markets [Pollock, 1994]. While there may be great appeal to securitization (and conduits that issue such securities), their complexity raises the cost of issuance and reduces investor demand. The instrument and institution has to be tailored to the needs of the markets. Instrument development (both bonds and MBS) must be adjusted to both constraints faced by lenders and investors. This suggests the use of simpler product variants, mortgage insurance and guarantees to facilitate investor acceptance and designs that will work in the current context. It is perhaps best to think of mortgage securities in an evolutionary context - starting with simple designs that do not tax the infrastructure or investor capabilities and introducing more complex designs as the market develops. Of course, it ultimately depends on the market - complexity can be good if it meets the specific needs of investors but can undermine liquidity and development of a secondary market.

It can be observed that there may be an excessive focus on institutional creation in advance of other fundamentals. Simply creating a secondary market institution will not create a market. For example in Russia there has been considerable technical assistance investment in the creation of the Agency for Mortgage Lending. The creation of this institution in 1997 preceded the drafting of a mortgage law and development of a primary market, as well as of the needed legal and regulatory framework for mortgage securities. Not surprisingly, it has done no commercial business. However, now that a comprehensive package of legal and regulatory reforms affecting both primary and 
secondary mortgage markets is actively considered, the role and activities of the Agency may become more significant.

Development efforts in many emerging countries have focused on institution development, particularly conduits with government involvement. In many cases they may be ahead of their time (or solutions in search of a problem). Governments and technical assistance providers may need to spend more time and resources on infrastructure development to allow individual issues of mortgage bonds and securities before investing in institutions.

\section{d) Different instruments are best suited to different contexts}

Although there may appear to be logical succession between mortgage bonds, a much older and a simpler instrument, and mortgage-backed securities, the two instruments in fact meet different needs. There is no linkage in the timing of their respective development, and ideally, both instruments should be simultaneously available in a diversified market.

The core differences between the pure, simplified models ${ }^{23}$ can be summarized as follows:

- The main potential achievements of securitization are:

- A rating enhancement due to the ability to disconnect the exposure on the mortgage loan portfolios from the exposure to the originators

- The complete transfer of financial risks

- The freeing-up of economic or regulatory capital

- A reduction in the cost of hedging the credit risk on the borrowers as a result in its diversification in larger pools.

However, the cost of such achievements is high, even independent of transaction expenses:

- The externalization of the credit risk implies an agency risk and cost for monitoring the underwriting and servicing of the loan. In addition, the cushioning of the risk requires the calibration of protection structures in order to obtain a significant rating enhancement.

- The pricing of the prepayment option passed to capital market investors requires a premium typically calculated on costly worst cases scenarios.

- Except for US agency issues, MBS, especially in the form of customized tranches, are illiquid securities. The reasons for this lie with a lack of standardization, valuation complexities, or the lack of proper information.

\footnotetext{
${ }^{23}$ Boundaries are being blurred, on the one hand by less-than full fledged securitization deals whereby originators retain a significant part of the credit risk, and sometimes the financial risks (limits set to the transfer of early repayments to investors), and on the other hand by the growing number of structured mortgage bonds
} 
- The relative advantages of mortgage bonds are symmetrical. They are in principle cheaper than MBS for the issuer on several accounts:

- The protection against issuer insolvency is embedded in the law, and does not require special credit enhancement structures.

- Mortgage bonds are simple, standardized securities that are easy to value and to trade as they are often disconnected from the profile of the loans.

- Mortgage bonds are relatively liquid securities, a feature reflected in their issuance spreads.

The counterparts for these advantages are the absence of capital relief and a lesser rating improvement than in the case of MBS.

This summarized comparison leads to a mapping of the contexts where each instrument appears mostly appropriate in a somewhat simplified manner.

The value of mortgage securities appear to be highest in the following cases:

- When lending institutions lack capital or the capability to properly mange financial risks or provide credible credit enhancement. It is on such a background that securitization developed in the United States and that securitization frameworks were established in Latin America in the mid 1990s. In such a context, it is likely that the benefit of the rating improvement on the issuing conditions exceed the cost inherent to the structure.

- For narrowly specialized lenders that lack the capacity for sound assetliability management or credit risk diversification either because of the concentration of their activity or because of the absence of hedging instruments in the financial markets.

Mortgage bonds, on the other hand, work well in the following situations:

- Relatively stable banking systems, where lending institutions enjoy a fairly good image among institutional investors and are not excessively capital constrained

- Lending institutions that have numerous lines of business that generate, to some extent, a diversification across their different portfolios and thus stronger perceived credit quality

- Deposit-taking institutions that need to replicate the cash flow characteristics of mortgage loans with embedded prepayment options by blending funding sources of different duration

- Institutions with nationwide or regional distribution able to create internally a mutualization of risks through different geographical areas.

These considerations suggest that, in an emerging mortgage market, mortgage bonds are likely to be used by commercial banks, contrary to the way they historically developed in Europe. Specialist mortgage banks, while simpler and more transparent institutions to evaluate and regulate, may not be as viable in a liberalized financial system. 


\section{e) Government can play a constructive role but its involvement is not a guarantee of success}

The success stories in our analysis all had important government support. As emphasized repeatedly in this text, the government must provide a strong legal and regulatory infrastructure. It is no accident that the most successful developing and developed market examples of mortgage security issuance are those countries with the strongest infrastructure.

In both Malaysia and Jordan, the government provided critical support in the form of seed capital (investing in a mortgage securities issuer) and incentives through the regulatory treatment of the products and securities. In Chile the government temporarily acted (for 2 years) as the main investor of mortgage bonds to help jump-start the market, and through its concurrent effort of creating institutional investors. Government support in Colombia took the form of tax incentives for investors and a temporary program of priced state guarantees. All of these initiatives allowed institutions to come to market with more favorable financing terms than can be done by private sector institutions alone. Government can also develop a secondary market in mortgage securities through liquidity support and required reserve eligibility. Providing guidance on disclosure and standardization are additional important roles for government.

Credit enhancement through a government guarantee can be an important way to catalyze a market. It is difficult to get investors to accept (or price) the complex risks of mortgage securities. A government guarantee, whether implicit through ownership or explicit, eliminates one risk allowing investors to focus on the others. But guarantees are dangerous as they can involve adverse selection and are detrimental to the government, and the government could end up with large contingent liabilities. Also, government support can create a monopoly that dominates a market and generates excess returns for its shareholders. Thus, a sunset provision should be considered in conjunction with government guarantees or financial support. ${ }^{24}$

One way to control the risk to government inherent in providing guarantees is to involve the private sector in a first-loss position. In theory, the risks can be better managed by the private sector as it has an incentive to properly manage and price risk in order to maximize the value of the franchise. Inevitably, however, this approach creates economic rents for the institutions benefiting from the guarantee and can lead to greater risk for government (e.g., through leveraging the guarantee) if not properly regulated and supervised.

A critical function for government is to build the proper regulatory framework. There must be proper safety and soundness regulation of issuers, and the framework must clearly define the structures, treatment of issuers (e.g., true sale) and investors (authority

\footnotetext{
${ }^{24}$ An example of an ex ante sunset is the government guarantee given to Caisse de Refinancement de Hypotecaire which was withdrawn on schedule after 3 years. Sallie Mae (the Student Loan Marketing Association) successfully dropped its government status in 1996.
} 
and incentive to invest). Proper tax treatment is critical in developing mortgage securitisation. First and foremost, there should not be double taxation of conduit or SPV issuance. There should not be excessive stamp duty or taxes on the registration of securities or their transfer. In addition, regulation must eliminate artificial arbitrages.

Selecting the right options for a given context may speed up the process. Selecting a model based on simplicity, type and number of primary market players, regional experiences, capital market infrastructure and legal and regulatory infrastructure is key to market development. Blind replication of practices prevailing on developed markets should be avoided. Investors should be integrated in the preparation of policy choices; skills and capacities are a sensitive factor for the acceptance of instruments.

\section{2) The Way Forward}

The track record of mortgage securities issuance in emerging markets has been spotty. Although there have been some clear success stories, there have been even more unsuccessful attempts. In many cases, despite a strong theoretical rationale for their introduction, the timing has not been right. In some cases, the primary market infrastructure was not sufficiently advanced and in others, the legal/regulatory infrastructure was not well developed. And in other cases, there was simply no demand for the tool by its supposed beneficiaries.

Should we get discouraged by this record? We do not think so. Introducing capital market finance in emerging markets is a complex, time consuming process. The development path is slow (new concepts, new tools, new business, needs of skill, etc.). Being slow does not mean unsuccessful. In many countries, efforts to create mortgage securities can be considered works in progress.

On the brighter side, as economies improve and demand for funds picks up, many banks may become more capital and/or liquidity constrained and look to the capital markets for funding. If so, then the demand for wholesale funding through mortgage securities will increase. This implies that countries should continue building capital market infrastructure.

If the development of mortgage securities imposes considerable efforts to meet these multiple prerequisites, the process often includes many useful reforms to improve the structure, standards and performance of primary mortgage markets. This dynamic process may take time, but often pays off at earlier stages at the level of primary mortgage markets, even if mortgage securities have not reached yet the desired sizeable scale effects from the funding perspective.

Mortgage instrument design is an important ingredient in the use of capital market funding as well. ARMs transfer most if not all interest rate risk to borrowers and may be unsuitable for volatile emerging markets. The introduction of FRMs is important for 
financial system stability. ${ }^{25}$ Even in a universal bank or portfolio lenders models, FRMs need to be funded in the capital markets. Efforts to create mortgage capital markets should include a product development component focusing on FRMs.

Governments can play an important catalytic role in the creation of mortgage securities. But they should be careful to not create institutions in advance of market need. Building proper infrastructure does not sound as compelling as creating the next Fannie Mae - but for many countries in the emerging world it is a better game plan. A major factor of efficiency, which is too often overlooked in the shadow of productivity and economies of scale, is the reduction of uncertainty for market players. Uncertainty has a cost, as the conditions for enhancing the credit quality of mortgage portfolios when borrowers default cannot be accurately assessed. It is the responsibility of governments to design a legal and regulatory framework so that clear and explicit provisions govern the status of mortgage securities - especially true sale conditions for MBS and protection against insolvency in case of mortgage bonds - thus securing the investors' commitments and limiting the risk premiums or cushions that are otherwise required.

In conclusion, the many benefits that mortgage securities can create for emerging economies justify continued effort in their development. Recent experience in introducing such securities provides many important lessons for countries seeking to go down this path. In this paper, we have tried to provide an overview of the benefits, pitfalls and experience in emerging markets. Hopefully these lessons will help prepare policy makers to deal with this complex and rewarding aspect of housing finance.

Michael Lea, Countrywide Financial Corporation

Loic Chiquier, The World Bank

Olivier Hassler, The World Bank

25 The fixed rate mortgages to which are referring are shorter term than the 15-30 year FRMs found in the US. The prepayment risk inherent in the US design can exacerbate volatility in the financial system and requires sophisticated investors and risk management tools. 


\section{Bibliography}

Banco Hipotecario, Annual Report 2002

Cagamas Berhad, Annual Reports 2002 and 2003

Department of the Treasury, Office of Federal Housing Enterprise Oversight, Securities and Exchange Commission: Enhancing Disclosure in the Mortgage-Backed Securities Markets, Staff report January 2003

European Mortgage Federation, Mortgage Banks and Mortgage Bonds in Europe, $3^{\text {rd }}$ ed., Brussels, 2001

European Mortgage Federation and Mercer Oliver Wyman, Study on the Financial Integration of European Mortgage Markets, October 2003

Fabozzi, F. ed., Handbook of Mortgage-Backed Securities, $5^{\text {th }}$ ed., McGraw-Hill, 2001

Fabozzi, F., C. Ramsey and M. Marz, Handbook of Non-Agency Mortgage-Backed Securities, $2^{\text {nd }}$. Ed., McGraw-Hill, 2000

Federal Deposit Insurance Corporation Assessing the Banking Industry's Exposure to an Implicit Government Guarantee of GSEs March 2004

Fitch Ratings, "As the Dust Settles: Current Performance of Argentine Structured Finance," April 2002

Gill, A., "Housing Finance and the Secondary Mortgage Market in Australia," Housing Finance International, December 1997

Hassler, O., "Mortgage Bonds,” World Bank 2003

Hong Kong Mortgage Corporation, Annual Report 2002

Lea, M., "Models of Secondary Mortgage Market Development," in M. Watnabe, ed., New Directions in Asian Housing Finance, International Finance Corp., 1999

Ladekarl, J., "Enhancing market liquidity for mortgage securities, ” World Bank 2001

Pollock, A., "Simplicity versus Complexity in the Evolution of Housing Finance Systems," Housing Finance International, March 1994

Pollock, A., "A New Housing Finance Option in the US: MPF vs. MBS," Housing Finance International, March 1999 
Stanton, T., Government Sponsored Enterprises, AEI Press, 2002

You, S.D., "Establishing a New Government-Sponsored Enterprise, the Korean National Mortgage Corporation," Housing Finance International, 2004 forthcoming

Zurich US, Press Release, March 20, 2000 